\title{
DEVELOPING MEASURES FOR THE EFFECTIVENESS OF DISTANCE EDUCATION AS REGARDS SUSTAINABILITY: THE MIXED METHOD APPROACH
}

\author{
Dr. Siti Haslina Md HARIZAN \\ ORCID: 0000-0001-6613-4165 \\ School of Distance Education \\ Universiti Sains Malaysia \\ Penang, MALAYSIA \\ Dr. Mohd Faiz HILMI \\ ORCID: 0000-0003-4548-0565 \\ School of Distance Education \\ Universiti Sains Malaysia \\ Penang, MALAYSIA
}

Received: 09/10/2020 Accepted: 23/12/2020

\begin{abstract}
Distance education has been acknowledged as a mechanism through which sustainable development can be achieved. The objective of the study is to develop the instrument that measures the effectiveness of distance education in inculcating sustainability among distance learners as the researchers have observed the absence of comprehensive and contextually appropriate measures for the effectiveness of distance education in nurturing sustainability. A mixed method research design was employed by following the six-phase sequential exploratory instrument development process. The quantitative validation of the instrument was done via a survey on 663 learners from the selected public universities in Malaysia. The SmartPLS 3 used by the researchers, produced a new 61-item measure of the effectiveness of distance education as regards sustainability. The findings have enabled the establishment of a comprehensive and contextually appropriate measurement tool applicable to a larger population of distance learners. It also provides an evaluation tool for practitioners in determining the effectiveness of distance education programs and courses that have led to the attainment of sustainability outcome among learners. Future studies may pursue further processes to improve the rigor and construct validation of the instrument besides uncovering other areas which are necessary to be incorporated in the scope of the measures.
\end{abstract}

Keywords: Distance education, distance learning, effectiveness, instrument development, Partial Least Squares - structural equation modelling, sustainability.

\section{INTRODUCTION}

Sustainability has become an important item for the agenda in institutions of higher education. Universities and other tertiary education providers have played a major role in knowledge creation and transforming decision-makers, policymakers, leaders, entrepreneurs and academics in finding solutions regarding sustainability in various aspects (Cortese, 2003). The United Nations decade for Education for Sustainable Development (DESD) 2005-2014 has encouraged innovative approaches in education (Buckler and Creech, 2014) so that meaningful contributions can be crafted to assist society in making the transition towards sustainability through both the formal education system and non-formal and informal learning settings. The Industrial Revolution 4.0 has propelled distance education programs to meet the need of learners over 
conventional learning whether in local or international settings by creating various learning opportunities. The Internet has transformed the way knowledge is communicated which has enlightened practitioners as regards the further potential of distance education in nurturing sustainability.

The recent outbreak of Covid-19 has also witnessed the resurgence and flexibility of distance education in delivering lessons to students (Castaman and Rodriguez, 2020; Gulseven et al., 2020). The potential of distance education to be the main educational mode can be further unleashed (Castaman and Rodriguez, 2020) following the outbreak. A silver lining in this pandemic is that governments have begun to realize their shortcomings in their educational policies and are offering updated distance education delivery systems extensively (Gulseven et al., 2020; Zhu and Liu, 2020). This has created an opportunity for distance education to be implemented in such a way that it is no longer a mere supplementary system but is a cogent, effective and distinctive solution. Since distance educations has had to serve this digital generation for their survival needs, its essence in nurturing sustainability has become unequivocally significant.

As far as past studies on sustainability in higher education are concerned, research has been carried out from several main perspectives. The first perspective has focused on management issues in sustainability of higher education which consists of topics such as sustainability assessment tools (Findler et al., 2018; Drahein, De Lima and Da Costa, 2019; Caeiro et al., 2020), sustainability reporting (Ana, Laura and Garcia-Benau, 2018; Coco, Remmer and Elisa, 2019; Sahar, Udo and Hossein, 2019), and challenges in managing sustainability in higher education (Molthan-Hill, Dharmasasmita and Winfield, 2016; Aleixo, Leal and Azeiteiro, 2018; Tormo-Carbo, Seguí-Mas and Oltra, 2018). The second perspective centers on the definition and elaboration of sustainable development competencies comprising those required by the university faculty in teaching the sustainability content and necessary competencies for student achievement (Grant, Lips-Wiersma and Soebagio, 2017; Foster and Stagl, 2018; Lavey, 2019) The third perspective is related to the implementation of higher education for sustainable development which addresses the purposes, scopes, and challenges of sustainable development associated with teaching and learning (Leal Filho and Dahms, 2018; Molderez and Fonseca, 2018; Michel, 2019). Although there was no bias towards a particular type of research methodology in past studies (Hallinger \& Chatpinyakoop, 2019), it is suggested that further research be done on the effectiveness of the different approaches in understanding the notion of higher education for sustainable development.

\section{PURPOSE OF THE STUDY}

Although distance education has been acknowledged in previous studies as a mechanism through which sustainable development can be achieved (Aleixo et al., 2018; Ramos et al., 2015), the learners' grasp of knowledge and practice regarding the concept of sustainability have been below expectation (Azeiteiro et al., 2015). This has made the assessment of the sustainability nurtured through distance education programs/ courses, a complex issue (Md Harizan \& Hilmi, 2019) and lacking, particularly in achieving the intended outcome of the sustainability agenda among students. New technologies on which modern distance education is based, are insufficient because they did not encourage the development of key learning skills, attitudes and values towards environmental conservation and sustainable development to the same level as face-to-face fieldwork (Oliveira, 2012; Oliveira et al., 2017). This situation has triggered a need to incorporate factors which would enhance the evaluation criteria underlying the effectiveness of distance education in nurturing awareness regarding sustainability and positive behaviors among learners.

To date, only a few studies which addressed the notion (Bacelar-Nicolau et al., 2009; Azeiteiro et al., 2015). While Bacelar-Nicolau et al. (2009) evaluated the extent towards which the Master's program, which comprised environmental and social sciences contents succeeded in expanding students' awareness and knowledge through e-learning, Azeiteiro et al. (2015) have conducted a descriptive analysis to assess the effectiveness of e-learning in delivering education related to sustainable development using a case study approach. However, the dimensions proposed by the findings of the study require further elaborations in terms of its indicators. Therefore, further investigation which enriches and transforms the dimensions into the form of items which provide operational definitions of the mentioned construct, to enable generalizability of findings in the future are required. Based on the identified gaps, the absence of a comprehensive, yet contextually appropriate measures of the effectiveness of distance education in nurturing sustainability has 
strongly motivated this study. The objectives of the study are to develop an instrument which measures the effectiveness of distance education as regards sustainability, and to validate the developed instruments among the distance learner population.

\section{LITERATURE REVIEW}

\section{Distance Education and Sustainability}

Distance education is an education system within which the teaching and learning actions are performed via communication technologies and mailing services by the teachers with the students being in different environments (Isman, 2005). It focuses on the pedagogy, technology, and instructional system designs that aim to deliver education to students who are not physically on site in a traditional classroom or campus (Tavukcu, Arap and Ozcan, 2011). The 'separateness' between teaching and learning forms a distinctive attribute of distance education which is deemed to be unique from the conventional face-to-face classroom setting, which requires the presence of instructor and students in the physical classroom setting. Such unique attributes enable distance education to overcome certain obstacles posed by conventional methods of lesson delivery by overcoming the problems of the dearth of qualified instructors, the geographical barriers between instructors, institutions, and student, and flexible time management (Of, Kahraman and Kudu, 2018).

Distance education is regarded as vital to sustainable education (Bourke and Simpson, 2009; May et al., 2011). The use of online technology can have an important role within education for sustainable development, namely for knowledge about sustainability, assessment practices competencies and outcomes assessment (Azeiteiro et al., 2015). Through distance education, universities can embrace sustainability in its different ways and domains and university graduates who have been confronted with ways to make our world more sustainable are able to tackle issues of sustainability and translate sustainable development declarations into real actions while reducing the carbon footprint in the higher education sector. (Bell et al., 2017). Distance education is more environmentally-sustainable than conventional forms of higher education (Roy, Potter and Smith, 2001; Herring and Roy, 2002; Roy, Potter and Yarrow, 2008). Distance-taught courses reported 90 percent less energy consumption and $\mathrm{CO} 2$ emissions than campus courses, although electronic delivery did not result in a reduction in energy or $\mathrm{CO} 2$ emissions compared to print-based distance learning (Herring and Roy, 2002). In another study of distance education in the UK, Roy, Potter, \& Yarrow (2008) found that the distance learning delivery method consumed $87 \%$ less energy and emitted $85 \%$ less CO2 than traditional brick and mortar classes. In Malaysia, it was found that distance education enables environmental preservation and facilitates sustainability particularly in reducing travel needs and thus, the carbon emission of the vehicles to/from campus can be lowered dramatically (Md Harizan et al., 2015; 2016; 2017). The sustainability criteria of distance education are remarkable during the Covid-19 pandemic, and have been found to be integrated satisfactorily with distance learning (Trung et al., 2020).

As distance education could ensure that sustainability is achieved to a great measure, the advances in technology are important for the future of distance education (Rovai and Downey, 2010; Venkatesh et al., 2013). By providing the appropriate tools and techniques for individuals to access and organize information, the existing distance education practices that maximize learner independence can be sustained (Swan, Garrison and Richardson, 2009).

\section{Effectiveness of Distance Education as regards Sustainability}

The concepts of sustainability affect the way educational providers in higher learning institutions operate, design the curricula and the method of delivering learning across different disciplines, and prepare the students to incorporate sustainable values, attitudes, and behaviors into their lives (Stephens, Hernandez, Roman, Graham, $\&$ Scholz, 2008). The evaluation of the effectiveness of distance education in delivering lessons was made by researchers in comparison to the conventional face-to-face instruction where both methods resulted in relatively the same learning outcomes and similar or higher student satisfaction levels. In addition, a negligible effect was noted between the degree of student-teacher interactions and the number of lessons learned (Shee and Wang, 2008; Campbell and Campbell, 2009, 2011; Salimi and Kornelus, 2018; Filipovska, Filipovska and Petreski, 2019). Although new technologies on which modern distance education is based on are important, they are not 
sufficient because they did not encourage the development of key learning skills, attitudes and values towards environmental conservation and sustainable development to the same level as face-to-face fieldwork (Oliveira, 2012; Oliveira et al., 2017). Such inconclusive findings have prompted the study to delve into the factors which would enhance the evaluation criteria underlying the effectiveness of distance education in nurturing awareness regarding sustainability and behavior among learners.

Studies have modelled the evaluation of the effectiveness of distance education in nurturing awareness regarding sustainability and behavior through several factors, some of which consisted of the distance learning experience of its learners (Wessel et al., 2019). Martinho et al. (2010) and Ana Pinto de Moura et al. (2010) found that an extremely high level of learners motivation and satisfaction with the online programs changed their attitudes about the environmental domains and contributed to others' changing their attitudes and behaviors. Besides, the study also found that online students are equally satisfied with their courses and revealed the same confirmed general expectations and acquired competencies which indicated that online education is as effective as face-to-face education. Figueiro and Raufflet (2015) reviewed several aspects which contribute toward the effectiveness of sustainability in education namely the pedagogical challenges, teaching techniques and curriculum orientation. Student's motivation, satisfaction, and issues pertaining to quality were also found to be strongly linked to the effectiveness of distance education in delivering the sustainability message (Goulimaris, 2015; Harris \& Martin, 2012; Markova et al., 2017). In order to gauge the effectiveness of distance education programs and courses with regards sustainability, a comprehensive and contextually appropriate measure is required by encapsulating the important and relevant indicators and items.

\section{METHOD}

The study used the mixed method research design by employing a sequential exploratory instrument development process. The process started with three main phases namely a series of qualitative interviews done with a small number of distance learners, followed by measurement instrument item generation, and the validation of the developed instruments via a quantitative survey done on the larger population of distance learners. The item development process was done according to the first six phases suggested by Onwuegbuzie, Bustamante and Nelson (2010) (refer to figure 1), recommendations and empirical validation (Rowan and Wulff, 2007; Imran and Yusoff, 2015) and exemplars from mixed methods studies (Rossiter, 2012; Witry et al., 2016).

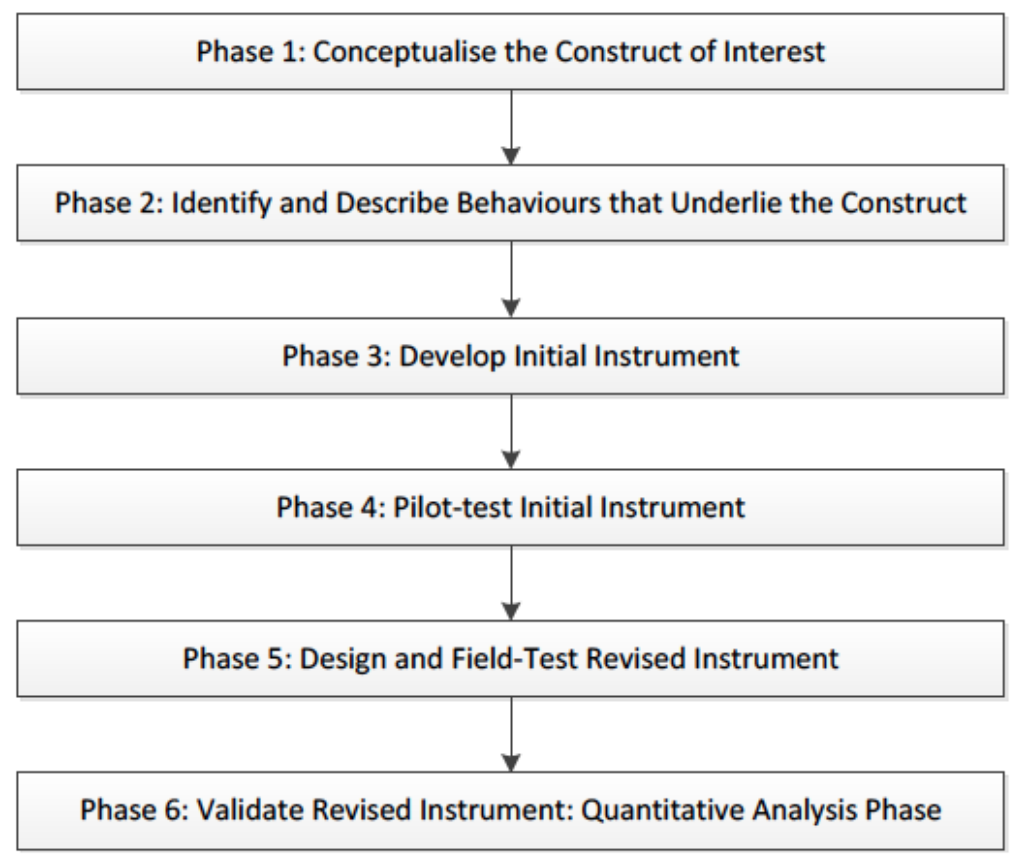

Figure 1. Instrument development and construct validation (IDVC) process (adapted from Onwuegbuzie, Bustamante and Nelson (2010) 


\section{Phase 1 - Conceptualisation of the Construct of Interest}

Phase 1 involved the development of the construct of interest i.e. the effectiveness of distance education as regards sustainability based on the extensive review of the literature. The initial dimensions of the construct were derived from Azeiteiro et al., (2015), which examined the effectiveness of education for sustainable development through e-learning in higher educational institutions based on several aspects namely the motivation of learners, expectations of their studies, satisfaction towards their studies, learning quality, and sustainability acquired competencies. Besides, the components raised by Bacelar-Nicolau et al., (2009) in evaluating course performance namely student motivation, student-content interaction, student-student interaction, student-teacher interaction, learning activities, type of evaluation, students' environmental citizenship attitudes and behaviors were also considered during the identification of the dimensions of the construct. The construct was then modified and contextually defined by incorporating attributes pertaining to distance education. Field experts were also consulted in establishing face validity for the construct.

\section{Phase 2 - Identify and Describe Behaviours that Underlie the Construct Using Qualitative Interviews}

Phase 2 dealt with the identification of items for the construct. This was done by performing qualitative interviews with a selected number of distance learners. A series of 72 semi-structured interviews, each lasting between 15 to 30 minutes was conducted among distance learners who were enrolled in a Bachelor's degree program of management studies delivered via distance education mode in a public university between January and February 2019. The objective was to locate factors that are important in determining the effectiveness of distance education in nurturing awareness regarding sustainability among learners. Participants were prompted to express their feelings, satisfactions, and expectations about their studies based on their experiences as the distance learners. Interviews were recorded, transcribed and coded using the NVivo software. The identification of items for the constructs was made by going through the interview transcripts and the coding by looking for statements underlying the earlier mentioned dimensions which define the effectiveness of distance education as regards sustainability namely expectations of distance education programs, learning quality, assessment, sustainability acquired competencies, satisfaction towards distance education programs, and motivation. Learning quality was further coded into seven sub-themes namely quality of online activities, quality of instructors, quality of teaching materials, quality of collaborative work, learning strategy, acquired competencies, and quality of the e-learning/Learning Management System. The reliability of procedure was ensured by having other researchers to perform the interview coding independently before an uninterrupted comparison was made until the final consensus was obtained.

\section{Phase 3 - Develop Initial Instrument}

Phase 3 consisted the generation of developed items for each construct. Initially, a total of 70 items were generated, comprising expectations of distance education programs ( 9 items), learning quality ( 35 items), assessment (3 items), sustainability acquired competencies (8 items), satisfaction towards distance education programs (4 items), and motivation (10 items). Seven initial sub-themes which constituted learning quality consisted of quality of online activities ( 6 items), quality of instructors (5 items), quality of teaching materials (5 items), quality of collaborative work (4 items), learning strategies (5 items), acquired competencies (5 items), and quality of e-learning/Learning Management System (5 items).

\section{Phase 4 - Pilot Test the Initial Instrument}

Phase 4 involved receiving feedback on the initial instrument. The items were arranged and checked by other researchers. The initial instrument also underwent a pilot test among a few distance learners in a campus. Ambiguous, leading, unclear, double-barreled, and duplicated items were either deleted or modified. Two items, motif3 (which focuses on job promotion) and expectation3 (which focuses on career advancement) which initially represented motivation and expectation respectively were found to be almost similar in meaning and thus, modified. 


\section{Phase 5 - Designing and Field Testing the Revised Instrument}

Phase 5 required researchers to refine and discard problematic items. This phase saw the distribution of a field test of the revised instrument to 600 randomly selected distance learners in a public university in Malaysia. The collected data was analyzed in an exploratory factor analysis with Promax rotation, which can be calculated more quickly than a direct oblimin rotation for large datasets (IBM, 2019). The results of the exploratory factor analysis showed that the KMO measure of sampling adequacy was 0.957 indicating sufficient inter-correlations while the Bartlett test of sphericity was significant (Chi-square $=27392.600$, $\mathrm{p}<0.01)$. Eigenvalues were greater than 1.0 and the total variance explained was $72.937 \%$ of total variance, which established the construct validity of items (Hair et al., 2006). Several initially coded items which formed learning quality were removed due to low communalities (learning_strategy4) and cross-loadings (quality_eportal2, quality_eportal3).

Eleven factors were generated comprising the initially coded themes; expectations of distance education programs (11 items), learning quality (32 items), assessment (3 items), sustainability acquired competencies (8 items), satisfaction towards distance education programs (4 items), and motivation (8 items). Learning quality constituted six factors namely quality of online learning activities (including e-learning / Learning Management System) (9 items), quality of instructors (6 items), quality of teaching materials (5 items), quality of collaborative work ( 4 items), acquired competencies ( 6 items), and quality of network connections ( 2 items). None of the earlier coded items of the learning strategy section was loaded into a distinct factor as they formed part of the items for other factors. The percent of variance explained by each factor were based on expectations of distance education programs (41.616\%), quality of online activities $(6.968 \%)$, sustainability acquired competencies $(5.070 \%)$, quality of instructors $(3.210 \%)$, quality of teaching materials $(2.849 \%)$, motivation $(2.733 \%)$, quality of collaborative work $(2.595 \%)$, satisfaction towards distance education programs (2.504\%), acquired competencies $(2.080 \%)$, assessment $(1.780 \%)$, and quality of network connection (1.532\%).

\section{Phase 6 - Quantitative Validation of the Revised Instrument}

Phase 6 required the quantitative validation of the instrument via a survey analysis. The measurement scales were operationalized using the 4-points Likert scale: 1 = "Strongly disagree", 2 = "Disagree", 3 = "Agree", 4 = "Strongly agree". Besides, the age, gender, marital status, monthly income, past education level, religion, race, occupation type, and field of study were included as items in the demographic profiles of the sample. A total of 1000 invitations to participate the online survey were sent via emails to undergraduate students who are currently enrolled in the off-campus or distance education programs offered by a selected number of Malaysian public universities. Permission to conduct the survey was granted by respective administrators of the programs before obtaining access to students' emails. The survey was done from August 2019 to November 2019. Data were coded into the Statistical Software for Analysis (SPSS) software. Analysis of frequency was done to examine the demographic profile of the respondents. The goodness of measures was further examined using SmartPLS3 software.

\section{FINDINGS}

A total of 1000 email invitations were sent to the students. 663 students responded, which constituted a response rate of $66.2 \%$. Most of the respondents were between 25 to 34 years old (54.9\%), female (60.5\%), married (58.5\%), having personal monthly income between RM2,000.00 to RM2,999.00 (37.9\%), and had previously obtained Diploma (55.5\%). The respondents were predominantly Muslims (87.5\%) from the Malay ethnic group (85.4\%), working in the government sector $(57.0 \%)$, and pursuing management studies (58.4\%).

The 'goodness of measures' was evaluated based on several criteria which comprise internal consistency reliability, convergent validity, and discriminant validity. Using the Smart-Partial Least Squares 3 software, the first criterion to be assessed was the internal consistency reliability. The Cronbach alpha, composite reliability, and coefficient Rho for all latent constructs exceeded 0.80 (see table 1 in Appendix). This indicated that the measures were internally consistent (Nunnally, 1978). Besides internal consistency 
reliability, both convergent and discriminant validity are also required to establish a good measurement model. Convergent validity can be evaluated by considering the outer loadings of the indicators and the average variance extracted (AVE) (Hair et al., 2017). Discriminant validity can be assessed based on twoapproaches namely the Fornell-Larcker criterion (Fornell \& Larcker, 1981) and cross-loadings (Chin, 1998). The Fornell-Larcker (1981) test for discriminant validity (see table 2 in Appendix) showed that the square root of each construct's AVE was greater than its highest correlation with any other construct, which was an indication of discriminant validity for the developed measurement items. In cross-loading (see table 1 in Appendix), each indicator loaded highest on the construct it is intended to measure (values higher than 0.70) and thus, concluding a discriminant validity of the developed measures (Chin, 1998). Several items were deleted due to low loading such as motif4 ("To increase one's competitiveness in the job") from the expectations of distance education programs construct, sac3 ("Since following a distance education program, I have always been involved in activities related to sustainability") from the sustainability acquired competencies construct, and motif8 ("I would like to improve my skills via distance education") from the motivation construct. A total of 61 items were finally derived in forming the measures for the effectiveness of distance education as regards sustainability. These items comprise the expectations of distance education programs (10 items), learning quality (30 items), assessment (3 items), sustainability acquired competencies (7 items), satisfaction ( 4 items), and motivation ( 7 items). Learning quality was generated by the quality of online learning activities (including e-learning / Learning Management System) (9 items), quality of instructors ( 6 items), quality of teaching methods (5 items), quality of collaborative work (4 items), and acquired competencies (6 items).

The Standardized Root Mean Square Residual (SRMR) and the Normed Fit Index (NFI) were used to measure the estimated model fit namely. For SRMR, a value less than 0.10 or of 0.08 is considered a good fit (Hu and Bentler, 1998). The closer the NFI to 1, the better the fit (Bentler \& Bonett, 1980). The table 3 (see Appendix) shows that this study's model's SRMR was 0.04 , while the NFI was 0.787 which is almost closed to 1 , indicating a good model fit.

\section{DISCUSSIONS AND CONCLUSION}

In summary, the objectives of the study are to develop an instrument which measures the effectiveness of distance education as regards sustainability and to validate the developed instruments among the distance learner population. The mixed method research design was employed by undertaking a sequential exploratory instrument development process based on phases as suggested by Onwuegbuzie, Bustamante and Nelson (2010). The mixed method item development combined both qualitative and quantitative approaches in generating the measurement items as extended from the earlier conceptualization of the education for sustainable development effectiveness through e-learning in higher education. The analysis produced a reliable and valid measurement instrument which comprised a total of 61-items for measuring the effectiveness of distance education as regards sustainability. The evidence from the study also shows that distance education is deemed to be effective in delivering sustainable development agendas to the learners via courses offered at institutions of higher education particularly in Malaysia as supported by earlier studies (Azeiteiro et al., 2015; Harris and Martin, 2012; Figueiro and Raufflet, 2015; Goulimaris, 2015; Md Harizan, Hilmi, \& Atan, 2015; 2016; 2017; Markova, Glazkova and Zaborova, 2017). Such enthusiasm must be backed by curriculum of the highest calibre, infrastructure, and support systems which will facilitate the students' learning process. This may in turn, enhance their motivation, expectations, and satisfaction towards distance education particularly in preparing them to be the agents of sustainability for the sake of national well-being. The outcome of the study has produced a measurement instrument that functions as a platform from which the extent of distance education's effectiveness in nurturing sustainability awareness and desired sustainability behaviors among learners can be assessed.

Theoretical implications comprise the contribution of the study in analyzing the effectiveness of distance education as regards sustainability from learners' perspectives. The study also has a methodological contribution as it has developed and validated the measurement scales for the mentioned constructs by expanding the earlier works of Azeiteiro et al. (2015). By incorporating inputs from distance learners, the mixed method approach enables the establishment of a newly developed measurement tools which is more 
comprehensive and contextually appropriate ensuring the generalizability of items to a larger population of study. The findings of the study will enable university administrators to acknowledge the significance of distance education not only as a delivery mode which embraces sustainability itself, but also as a mode through which the sustainability curriculum can be delivered effectively to the learners. The findings may also produce an evaluation tool which will benefit academic assessors and auditors in determining the viability of courses delivered via distance education.

The outcome of having sustainable distance education programs will be the ability to develop the competencies necessary to live sustainable lifestyles and create sustainable livelihoods among learners. It also prepares the institutions to survive the fourth industrial revolution by embarking on the technologicalbased learning to help individuals, particularly those who have missed out on their tertiary education early in life, thus, supporting the country's aims in attaining the United Nation's Sustainable Development Goal 4, by promoting lifelong learning opportunities for all. The national agenda of building a knowledge-based society and a nation of lifelong learners while nurturing skills and values that promote sustainable economic progress and development may also be achieved. Distance education will also pave the nation towards the betterment of the world through the attainment of the United Nation's Sustainable Development Goal 13, having been acknowledged as an environmentally friendly learning option by taking urgent action to combat climate change and its impact.

This study has a limitation. It only employed the first six phases of instrument development and construct validation suggested by Onwuegbuzie, Bustamante and Nelson (2010) in establishing sufficient validity required for a quantitative instrument. Further evaluations of instrument development are strongly suggested to improve the rigor and construct validation of the revised instrument as well as to uncover other areas for further growth of the instrument. This can be done by validating the revised instruments via the qualitative analysis phase, performing mixed analysis (which comprise the qualitative-dominant crossover analyses followed by quantitative-dominant crossover analyses), and instrument development evaluation. Besides, the measurement instrument was developed based on the perspective of distance learners within the Malaysian educational setting. Future research may incorporate other countries' educational settings and learning cultures to increase its operational generalizability.

In conclusion, distance education has been deemed to be effective in transforming sustainability agenda via courses taught at higher educational institutions. However, studies pertaining specifically to the effectiveness in transforming sustainable development agenda through courses and programs via distance education mode have been lacking, particularly in achieving the intended outcome of the agenda among students. Moreover, the extent to which the notion can be defined is still unclear and vague which may be caused by the prevailing usage of existing heterogeneity of measurement scales. A comprehensive, yet contextually appropriate measure is required to provide a concrete operational definition for the above-mentioned notion. Using a mixed method approach, this study has proposed a validated 61-items measurement instrument for measuring the effectiveness of distance education as regards sustainability. The study contributes theoretically by transforming the existing descriptive definition of the construct into the empirically based operational definition to enhance the generalizability of future studies to a larger population. The study has strengthened the significance of distance education, not only as a delivery mode which embraces sustainability itself, but also as a mode through which the sustainability curriculum can be delivered effectively to the learners. The developed measures may also serve as an evaluation tool to facilitate academic assessors and auditors in determining the sustainability impact of courses/programs delivered via distance education. Future development may pursue further processes to improve the rigor and construct validation of the instrument besides uncovering other areas which are necessary to be incorporated in the scope of the measures. Future studies may also enhance the operational generalizability of the measures by incorporating other countries' educational settings and learning cultures.

Acknowledgements: We would like to thank Universiti Sains Malaysia for supporting the research (Grant no. 304/PJJAUH/6315204) and Ms Nur Hanis Alisa Md Hasri for assistance. 


\section{BIODATA and CONTACT ADDRESSES of AUTHORS}

Dr. Siti Haslina Md HARIZAN is a Senior Lecturer of management section at School of Distance Education, Universiti Sains Malaysia. She gained her Bachelor of Technology (Hons.) Information System (Minor in Corporate Management) from Universiti Teknologi PETRONAS, Malaysia and later her MBA and PhD from Universiti Sains Malaysia. She has been working at Universiti Sains Malaysia since 2014. Her research interests include Sustainability in Distance Education, Environmentally Sustainable/ Green Consumer Behavior and Environmentally Sustainable Marketing. She has published research articles in various indexed and international peer-reviewed journals, conference proceedings, and book chapters.

Siti Haslina Md HARIZAN

School of Distance Education

Address: Universiti Sains Malaysia, 11800 Penang, Malaysia

Phone: +604 6534569

E-mail: sitihaslina@usm.my

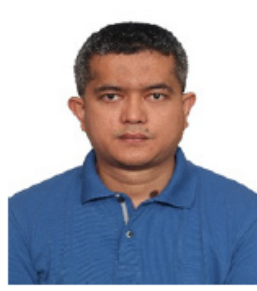

Dr. Mohd Faiz HILMI is a Senior Lecturer of management section at School of Distance Education, Universiti Sains Malaysia. He gained his BBA from Washington State University, USA, MBA from Universiti Utara Malaysia and DBA from Universiti Sains Malaysia. He has been working at Universiti Sains Malaysia since 2009. His research interests include Technology and Innovation Management, Innovative Behavior, e-Learning and Distance Education. He has published research articles in indexed and international peer-reviewed journals and conference proceedings.

Mohd Faiz HILMI

School of Distance Education

Address: Universiti Sains Malaysia, 11800 Penang, Malaysia

Phone: +604 6534560

E-mail: faiz@usm.my

\section{REFERENCES}

Aleixo, A. M., Leal, S., \& Azeiteiro, U. M. (2018). Conceptualization of sustainable higher education institutions, roles, barriers, and challenges for sustainability: An exploratory study in Portugal. Journal of Cleaner Production, 172, 1664-1673.

Ana Pinto de Moura, Luís Miguel Cunha, Ulisses Miranda Azeiteiro, Luísa Aires, Pedro Graca, M. D. V. de A. (2010). Food consumer science post-graduate courses: comparison of face-to-face versus online delivery systems. British Food Journal, 112(5), 544-556.

Azeiteiro, U. M., Bacelar-Nicolau, P., Caetano, F. J. P., \& Caeiro, S. (2015). Education for sustainable development through e-learning in higher education: Experiences from Portugal. Journal of Cleaner Production, 106, 308-319.

Bacelar-Nicolau, P., Caeiro, S., Martinho, A. P., Azeiteiro, U. M., \& Amador, F. (2009). E-learning for the environment: The Universidade Aberta (Portuguese Open Distance University) experience in the environmental sciences post-graduate courses. International Journal of Sustainability in Higher Education, 10(4), 354-367.

Bell, S., Douce, C., Caeiro, S., Teixeira, A., Martín-Aranda, R., \& Otto, D. (2017). Sustainability and distance learning: a diverse European experience? Open Learning, 32(2), 95-102.

Bentler, P. M., \& Bonett, D. G. (1980). Significance Tests and Goodness-of-Fit in the Analysis of Covariance Structures. Psychological Bulletin, 88, 588-600. 
Bourke, J., \& Simpson, O. (2009). Sustainability in education: Is distance learning an answer? Retrieved from http://repository.openpolytechnic.ac.nz/handle/11072/1434

Buckler, C., \& Creech, H. (2014). Shaping the Future We Want. United Nations Educational, Scientific and Cultural Organization. https://doi.org/10.5363/tits.11.4_46

Caeiro, S., Sandoval Hamon, A. L., Martins, R., \& Bayas Aldaz, E. C. (2020). Sustainability Assessment and Benchmarking in Higher Education Institutions-A Critical Reflection. Sustainability, 12(543), $1-30$.

Campbell, D., \& Campbell, J. (2009). Environmental Benefits Associated with Online Instruction. Retrieved from http://digitalcommons.calpoly.edu/csusymp2009/17/

Campbell, J., \& Campbell, D. (2011). Distance Learning is Good for the Environment: Savings in Greenhouse Gas Emissions. Online Journal of Distance Learning Administration, 14(4), 15563847.

Castaman, A. S., \& Rodriguez, R. A. (2020). Distance Education in the COVID crisis - 19: an experience report. Research, Society and Development, 9(6), 1-26.

Chin, W. W. (1998). The partial least squares approach for structural equation modeling. In G. A. Marcoulides (Ed.), Modern methods for business research (pp. 295-236). London: Lawrence Erlbaum Associates.

Coco, K., Remmer, S., \& Elisa, G. (2019). Structural key factors of participatory sustainability reporting for universities. International Journal of Sustainability in Higher Education, 20(6), 1080-1098.

Cortese, A. D. (2003). The Critical Role of Higher Education in Creating a Sustainable Future. Planning for Higher Education, Mar-May, 15-22.

Drahein, A. D., De Lima, E. P., \& Da Costa, S. E. G. (2019). Sustainability assessment of the service operations at seven higher education institutions in Brazil. Journal of Cleaner Production, 212, 527-536.

Figueiro, P. S., \& Raufflet, E. (2015). Sustainability in higher education: A systematic review with focus on management education. Journal of Cleaner Production, 106, 22-33.

Filipovska, B., Filipovska, E., \& Petreski, D. (2019). The development of modern distance education. In 2-nd International Scientific Conference MILCON (pp. 226-233). Skopje, North Macedonia.

Findler, F., Schonherr, N., Lozano, R., \& Stacherl, B. (2018). Assessing the impacts of higher education institutions on sustainable development-an analysis of tools and indicators. Sustainability (Switzerland), 11(1), 1-19.

Fornell, C. \& Larcker, D. F. (1981). Evaluating Structural Equation Models with Unobservable Variables and Measurement Error. Journal of Marketing Research, 18(1), 39-50.

Foster, G., \& Stagl, S. (2018). Design, implementation, and evaluation of an inverted (flipped) classroom model economics for sustainable education course. Journal of Cleaner Production, 183, 1323-1336.

Goulimaris, D. (2015). The relation between distance education students' motivation and satisfaction. Turkish Online Journal of Distance Education, 16(2), 13-27.

Grant, P., Lips-Wiersma, M., \& Soebagio, V. (2017). Developing Essential Competencies of Sustainability Educators Teaching and Modelling Systems Thinking Through Partnership Learning. Journal of Business Ethics Education, 14, 241-259.

Gulseven, Osman and Al Harmoodi, Fatima and Al Falasi, Majid and ALshomali, Ibrahim, How the COVID-19 Pandemic Will Affect the UN Sustainable Development Goals? (May 4, 2020). Available at SSRN: https://ssrn.com/abstract=3592933

Hair, J.F., Black, W. C., Babin, B. J., Anderson, R. E., \& \& Tatham, R. L. (2006). Multivariate Data Analysis (Sixth Edition). New Jersey, USA: Pearson Education Inc.

Hair, Joseph F., M.Hult, G. T., Ringle, C. M., \& Sarstedt, M. (2017). A Primer on Partial Least Squares Structural Equation Modeling (PLS-SEM) (Second Edition). California, U.S.A.: SAGE Publications Inc. 
Hallinger, P., \& Chatpinyakoop, C. (2019). A bibliometric review of research on higher education for sustainable development, 1998-2018. Sustainability (Switzerland), 11(8), 1-20.

Harris, H., \& Martin, E. (2012). Student Motivations for Choosing Online Classes. International Journal for the Scholarship of Teaching \& Learning, 6(2), 1-8.

Herring, H., \& Roy, R. (2002). Sustainable services, electronic education and the rebound effect. Environmental Impact Assessment Review, 22(5), 525-542.

Hu, L., \& Bentler, P. M. (1998). Fit indices in covariance structure modeling: Sensitivity to underparameterized model misspecification. Psychological Methods, 3(4), 424-453.

IBM. (2019). Factor Analysis Rotation. Retrieved December 27, 2019, from https://www.ibm.com/support/ knowledgecenter/SSLVMB_24.0.0/spss/base/idh_fact_rot.html

Imran, A., \& Yusoff, R. M. (2015). Empirical validation of qualitative data: A mixed method approach. International Journal of Economics and Financial Issues, 5, 389-396.

Isman, A. (2005). Uzaktan Egitim. Ankara: Ogreti Yayincilik.

Lavey, W. G. (2019). Teaching the health impacts of climate change in many American higher education programs. International Journal of Sustainability in Higher Education, 20(1), 39-56.

Leal Filho, W., \& Dahms, L.-M. (2018). Incorporating Sustainable Development Issues in Teaching Practice. In W. Leal Filho (Eds.), Implementing Sustainability in the Curriculum of Universities: Approaches, Methods and Projects. (pp. 323-330). Cham: Springer International Publishing.

Markova, T., Glazkova, I., \& Zaborova, E. (2017). Quality Issues of Online Distance Learning. Procedia Social and Behavioral Sciences, 237(June 2016), 685-691.

Martinho, A. P., Nicolau, P. B., Caeiro, S., Amador, F., \& Oliveira, C. (2010). Environmental Citizenship and Participation the Role of Education Programs. 14th European Roundtable on Sustainable Consumption and Production (ERSCP) Conference and the 6th Environmental Management for Sustainable Universities (EMSU) Conference, (2010), 1-17.

May, R., Cox, V., Kroder, S., \& Franklin, G. (2011). The Overlooked Dimension of Sustainable Education. Online Submission. Retrieved from http://eric.ed.gov/?id=ED529903

Md Harizan, S.H., \& Hilmi, M. F. (2019). Effectiveness of Distance Education on Sustainability from Learners' Perspective. International Journal of Innovation, Creativity and Change, 8(6), 167-181.

Md Harizan, S.H., Hilmi, M.F., \& Atan, H. (2017). Distance Education as an Environmentally-Friendly Learning Option? Empirical Evidence from Malaysia. Journal of Humanities, Language, Culture and Business, 1(1), 74-83.

Md Harizan, S.H., Hilmi, M.F., \& Atan, H. (2015). Distance Education as an Environmentally-Friendly Learning Option. Journal of Global Business and Social Entrepreneurship, 1(2). Retrieved from http://gbse.com.my/isi16/GBSE 1(2), 1-7 (2015).pdf

Md Harizan, S.H., Hilmi, M.F., \& Atan, H. (2016). Exploring Acceptance Towards Environmental Sustainability of Distance Education in Malaysia. Management of Sustainable Development, 8(2), $17-24$.

Michel, J. O. (2019). An assessment of teaching and learning about sustainability across the higher education curriculum. Environmental Education Research. Columbia University.

Molderez, I., \& Fonseca, E. (2018). The efficacy of real-world experiences and service learning for fostering competences for sustainable development in higher education. Journal of Cleaner Production, 172, 4397-4410.

Molthan-Hill, P., Dharmasasmita, A., \& Winfield, F. M. (2016). Academic Freedom, Bureaucracy and Procedures: The Challenge of Curriculum Development for Sustainability. In J. P. Davim \& W. Leal Filho (Eds.), Challenges in Higher Education for Sustainability. (pp. 199-215). Cham: Springer International Publishing. 
Nunnally, J. C. (1978). Psychometric Theory (Second). New York: McGraw-Hill.

Of, M., Kahraman, K., \& Kudu, M. (2018). Computer Programming Students' Attitudes in Distance. The Online Journal of Distance Education and E-Learning, 6(2), 41-45.

Oliveira, S. de. (2012). E-textbooks usage by students at Andrews University: A study of attitudes, perceptions, and behaviors. Proceedings of the IATUL Conferences. Retrieved from https://docs. lib.purdue.edu/cgi/viewcontent.cgi?article $=1122 \&$ context $=$ iatul

Oliveira, J. H., Giannetti, B. F., Agostinho, F., \& Almeida, C. M. V. B. (2018). Decision making under the environmental perspective: Choosing between traditional and distance teaching courses. Journal of Cleaner Production, 172, 4303-4313.

Onwuegbuzie, A. J., Bustamante, R. M., \& Nelson, J. A. (2010). Mixed research as a tool for developing quantitative instruments. Journal of Mixed Methods Research, 4(1), 56-78.

Ramos, T. B., Caeiro, S., Van Hoof, B., Lozano, R., Huisingh, D., \& Ceulemans, K. (2015). Experiences from the implementation of sustainable development in higher education institutions: Environmental Management for Sustainable Universities. Journal of Cleaner Production, 106, 3-10.

Ringle, Christian M., Wende, Sven, \& Becker, Jan-Michael. (2015). SmartPLS 3. Bonningstedt: SmartPLS. Retrieved from http://www.smartpls.com

Rossiter, J. R. (2012). How to use qualitative research to design a managerially useful E-service questionnaire. Journal of Theoretical and Applied Electronic Commerce Research, 7(2), 52-58.

Rovai, A. P., \& Downey, J. R. (2010). Why some distance education programs fail while others succeed in a global environment. Internet and Higher Education, 13(3), 141-147.

Rowan, N., \& Wulff, D. (2007). Using qualitative methods to inform scale development. The Qualitative Report, 12(3), 450-466.

Roy, R., Potter, S., \& Smith, M. (2001). Exploring ways to reach sustainability in transport, housing and higher education. In Ninth International Conference of Greening of Industry Network,. Retrieved from https://gin.confex.com/gin/archives/2001/papers/56.pdf

Roy, R., Potter, S., \& Yarrow, K. (2008). Designing low carbon higher education systems: Environmental impacts of campus and distance learning systems. International Journal of Sustainability in Higher Education, 9(2), 116-130.

Sahar, S., Udo, B., \& Hossein, R. A. (2019). Comprehensive sustainability reporting in higher education institutions. Social Responsibility Journal, 15(2), 155-170.

Salimi, A. Y., \& Kornelus, A. (2018). An investigation of student satisfaction with distance education courses based on student characteristics. Journal of Business \& Educational Leadership, 7(1), 146-155.

Shee, D. Y., \& Wang, Y. S. (2008). Multi-criteria evaluation of the web-based e-learning system: A methodology based on learner satisfaction and its applications. Computers and Education, 50(3), 894-905.

Sitzmann, T., Kraiger, K., Stewart, D., \& Wisher, R. (2006). The comparative effectiveness of web-based and classroom instruction: A meta-analysis. Personnel Psychology, 59(3), 623-664.

Stephens, J., Hernandez, M., Roman, M., Graham, A., \& Scholz, R. (2008). Higher education as a change agent for sustainability in different cultures and contexts. International Journal of Sustainability in Higher Education, 9(3), 317-338.

Swan, K., Garrison, D. R., \& Richardson, J. C. (2009). A constructivist approach to online learning: The community of inquiry framework. Information Technology and Constructivism in Higher Education: Progressive Learning Frameworks, (April 2016), 43-57.

Tavukcu, T., Arap, I., \& Ozcan, D. (2011). General overview on distance education concept. Procedia Social and Behavioral Sciences, 15, 3999-4004. 
Tormo-Carbo, G., Seguí-Mas, E., \& Oltra, V. (2018). Business ethics as a sustainability challenge: Higher education implications. Sustainability (Switzerland), 10(8), 1-17.

Trung, T., Hoang, A.-D., Nguyen, T. T., Dinh, V.-H., Nguyen, Y.-C., \& Pham, H.-H. (2020). Dataset of Vietnamese student's learning habits during COVID-19. Data in Brief, 30, 105682.

Venkatesh, V., Jedwab, J., Rabah, J., Thomas, T., Varela, W., \& Alexander, K. (2013). From disconnected to connected: Insights into the Future of Distance Education and Web 2.0 Tools in Higher Education. International Journal of Technologies in Higher Education, 10(3), 6-13.

Wessel, P. R., Ryan, A., Anisa, K., \& Richelle, P. (2019). Creating a context for campus sustainability through teaching and learning: The case of open, distance and e-learning. International Journal of Sustainability in Higher Education, 20(3), 530-547.

Witry, M. J., Wesely, P. M., Goedken, A. M., Ernst, E. J., Sorofman, B. A., \& Doucette, W. R. (2016). Development of a medication monitoring attitude measure using a mixed methods item development process. International Journal of Pharmacy Practice, 24(1), 49-59.

Zhu, X., \& Liu, J. (2020). Education in and After Covid-19: Immediate Responses and Long-Term Visions. Postdigital Science and Education, 2(10). https://doi.org/10.1007/s42438-020-00126-3. 
APPENDIX

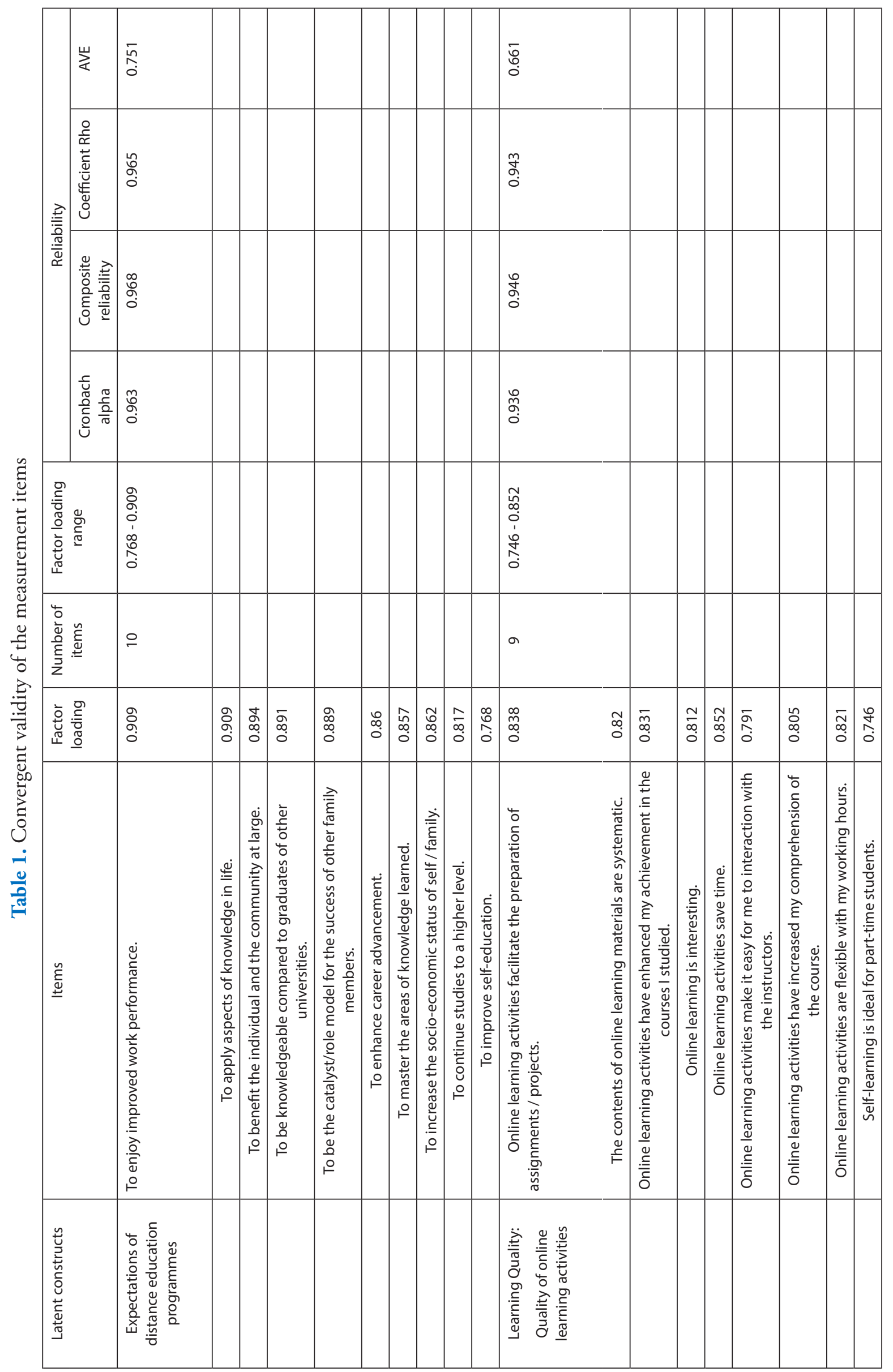




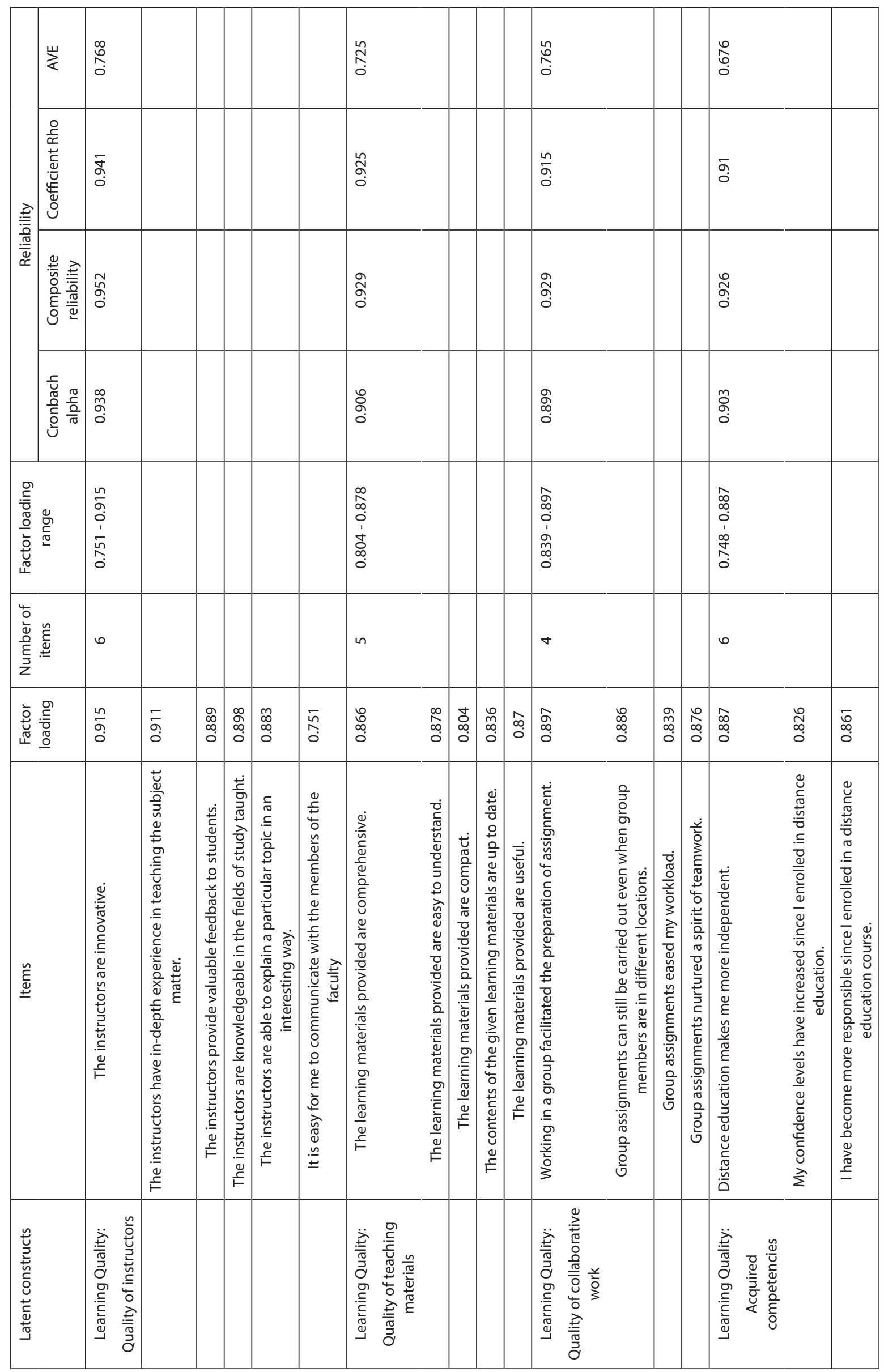




\begin{tabular}{|c|c|c|c|c|c|c|c|c|c|c|c|c|c|c|c|c|}
\hline$\underset{\gtrless}{\stackrel{u}{\gtrless}}$ & & & & 尺̊. & & & $\begin{array}{l}\text { 芯 } \\
0\end{array}$ & & & & & & & 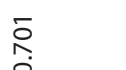 & & \\
\hline 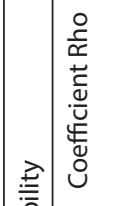 & & & & $\begin{array}{l}\infty \\
\text { ò }\end{array}$ & & & \begin{tabular}{l}
\multirow{\sigma}{*}{} \\
oू
\end{tabular} & & & & & & & $\underset{\substack{\text { Do } \\
0}}{\mathbb{N}}$ & & \\
\hline 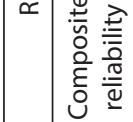 & & & & $\begin{array}{l}\infty \\
\text { ò } \\
0\end{array}$ & & & ふે & & & & & & & $\begin{array}{l}\text { O̊ } \\
\text { Oे }\end{array}$ & & \\
\hline 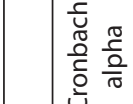 & & & & 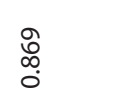 & & & $\bar{\sigma}$ & & & & & & & $\begin{array}{l}\infty \\
\aleph_{\infty}^{\infty} \\
0\end{array}$ & & \\
\hline 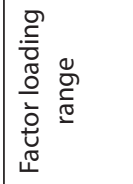 & & & & $\begin{array}{l}\infty \\
\bar{\sigma} \\
0 \\
\dot{\sim} \\
\infty \\
\infty \\
0\end{array}$ & & & $\begin{array}{l}\overline{0} \\
0 \\
0 \\
1 \\
\frac{1}{n} \\
0 \\
0\end{array}$ & & & & & & & $\begin{array}{l}\hat{o} \\
0 \\
0 \\
0 \\
1 \\
\infty \\
\stackrel{0}{0} \\
\stackrel{0}{0}\end{array}$ & & \\
\hline 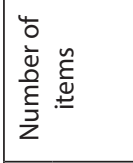 & & & & $m$ & & & $\wedge$ & & & & & & & $\sigma$ & & \\
\hline 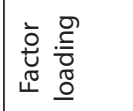 & $\underset{\substack{m \\
\infty \\
0}}{0}$ & $\begin{array}{l}\stackrel{\infty}{\circ} \\
\stackrel{0}{0}\end{array}$ & 泾 & $\stackrel{\infty}{\vdots}$ & $\begin{array}{l}m \\
\sigma \\
o\end{array}$ & $\begin{array}{c}\tilde{N} \\
\infty \\
0 \\
0\end{array}$ & $\begin{array}{c}\overline{1} \\
\substack{0 \\
0}\end{array}$ & 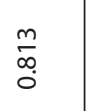 & $\stackrel{\substack{\infty \\
0}}{0}$ & $\begin{array}{l}\stackrel{\infty}{\infty} \\
\stackrel{0}{0}\end{array}$ & 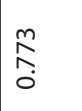 & $\begin{array}{l}\infty \\
\stackrel{\infty}{0} \\
\hat{0}\end{array}$ & $\begin{array}{l}\bar{n} \\
\hat{0}\end{array}$ & $\begin{array}{cc}\stackrel{\infty}{\infty} & \stackrel{\infty}{0} \\
0 & \stackrel{0}{0}\end{array}$ & $\begin{array}{l}\hat{n} \\
\text { on } \\
0\end{array}$ & $\begin{array}{l}0 \\
\stackrel{0}{0} \\
0 \\
0\end{array}$ \\
\hline$\underset{\underline{\underline{E}}}{\stackrel{u}{\underline{E}}}$ & 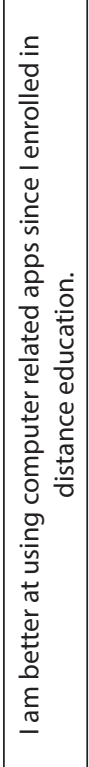 & 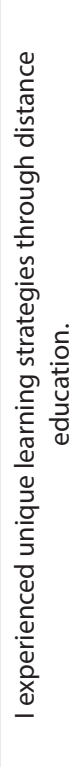 & 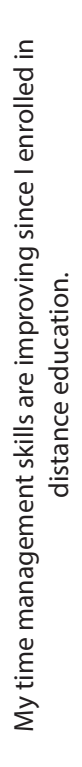 & 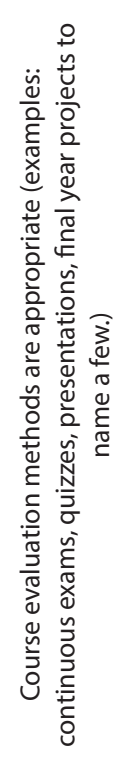 & 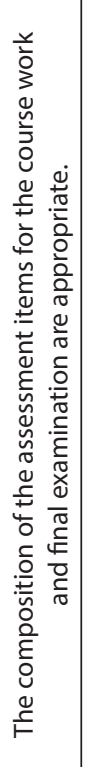 & 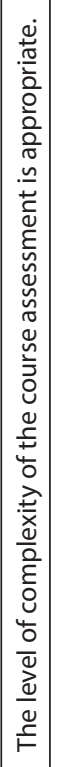 & 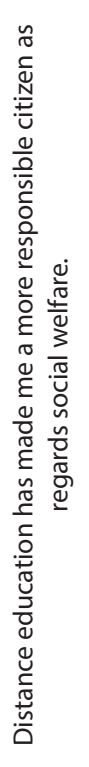 & 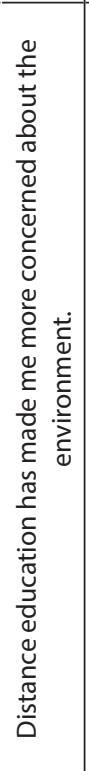 & 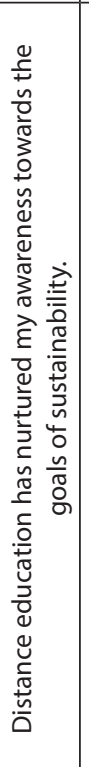 & 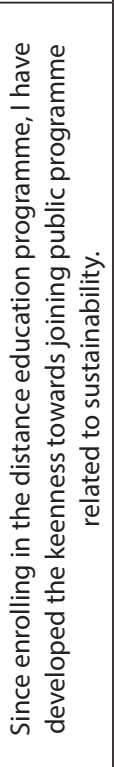 & 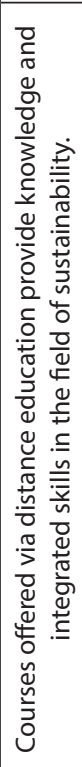 & 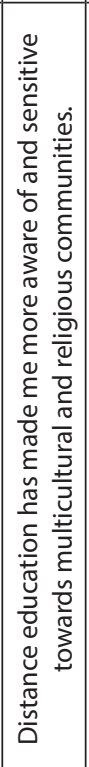 & 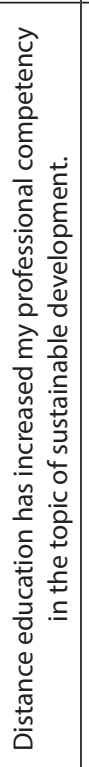 & 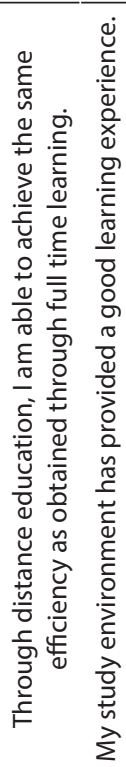 & 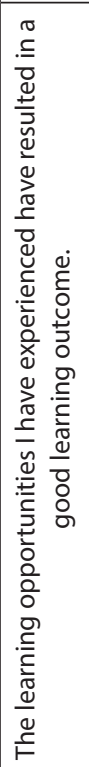 & 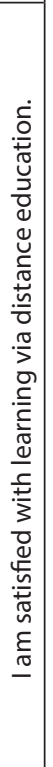 \\
\hline 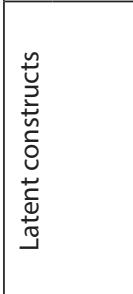 & & & & 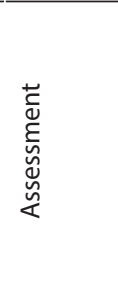 & & & 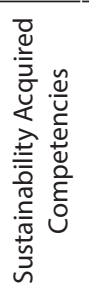 & & & & & & & 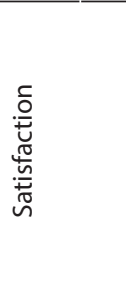 & & \\
\hline
\end{tabular}




\begin{tabular}{|c|c|c|c|c|c|c|c|}
\hline$\stackrel{\mathrm{U}}{\gtrless}$ & $\begin{array}{l}\hat{\hat{\alpha}} \\
0 \\
0\end{array}$ & & & & & & \\
\hline 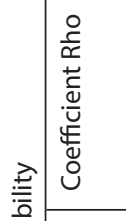 & $\begin{array}{l}\stackrel{n}{\sigma} \\
\sigma \\
0\end{array}$ & & & & & & \\
\hline 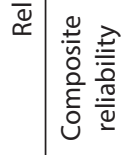 & જે & & & & & & \\
\hline 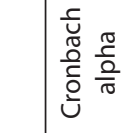 & হু & & & & & & \\
\hline 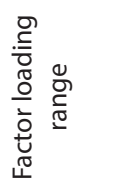 & 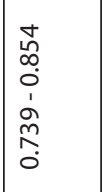 & & & & & & \\
\hline 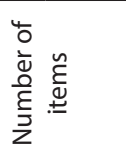 & $\wedge$ & & & & & & \\
\hline 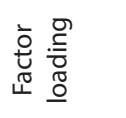 & 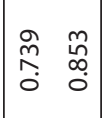 & 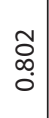 & 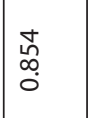 & $\begin{array}{c}\hat{1} \\
\infty \\
0 \\
0\end{array}$ & $\underset{\substack{\text { ò } \\
0 \\
0}}{ }$ & 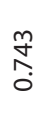 & \\
\hline & 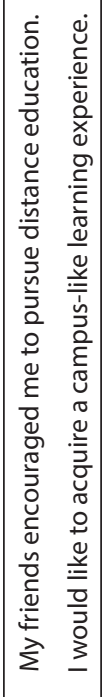 & 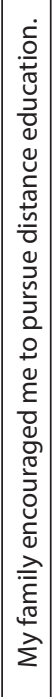 & 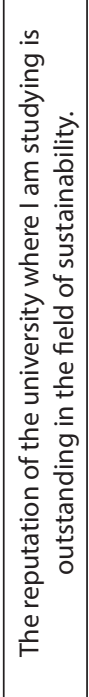 & 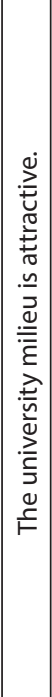 & 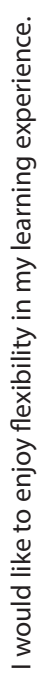 & 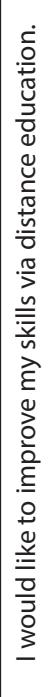 & 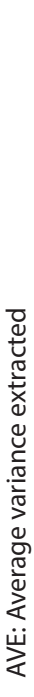 \\
\hline 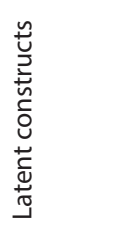 & 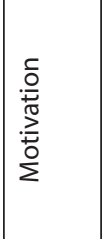 & & & & & & \\
\hline
\end{tabular}




\begin{tabular}{|c|c|c|c|c|c|c|c|c|c|c|}
\hline 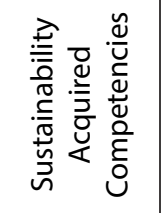 & & & & & & & & & & 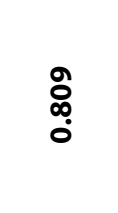 \\
\hline 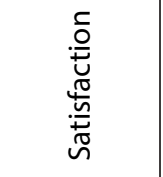 & & & & & & & & & $\begin{array}{c}\hat{\infty} \\
0 \\
0 \\
0\end{array}$ & $\underset{0}{\mathbb{J}}$ \\
\hline 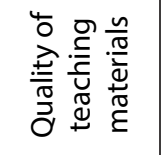 & & & & & & & & 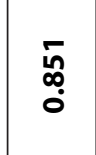 & $\begin{array}{l}\hat{O} \\
\hat{n} \\
0 \\
0\end{array}$ & $\stackrel{m}{\text { fo }}$ \\
\hline 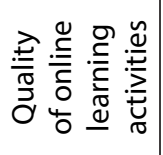 & & & & & & & $\underset{\substack{m \\
0 \\
0}}{0}$ & $\overline{\overleftarrow{\sigma}}$ & م̂n & ồ \\
\hline 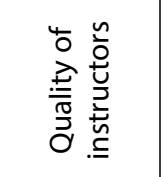 & & & & & & 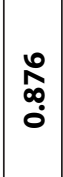 & $\begin{array}{l}0 \\
0 \\
0\end{array}$ & $\frac{N}{0}$ & $\begin{array}{l}\text { مิ } \\
\text { مै }\end{array}$ & $\stackrel{n}{\Im}$ \\
\hline 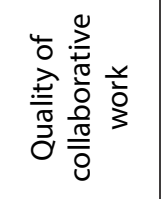 & & & & & $\begin{array}{l}n \\
\stackrel{n}{0} \\
0 \\
0\end{array}$ & $\begin{array}{l}\infty \\
\stackrel{\infty}{0} \\
0\end{array}$ & \begin{tabular}{l}
$\infty$ \\
$\stackrel{o}{0}$ \\
\multirow{0}{0}{}
\end{tabular} & $\begin{array}{l}\stackrel{\infty}{f} \\
\stackrel{0}{0}\end{array}$ & \begin{tabular}{l} 
ț \\
\multirow{0}{0}{}
\end{tabular} & 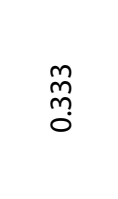 \\
\hline 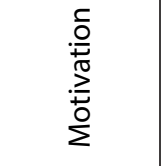 & & & & $\begin{array}{l}\infty \\
\stackrel{0}{\infty} \\
0 \\
0\end{array}$ & $\begin{array}{l}\stackrel{n}{\hat{n}} \\
\tilde{n} \\
0\end{array}$ & $\begin{array}{l}\text { in } \\
\text { in }\end{array}$ & $\begin{array}{l}\hat{o} \\
\text { ڤn } \\
0\end{array}$ & 号 & $\begin{array}{l}\stackrel{n}{N} \\
\text { On }\end{array}$ & 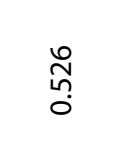 \\
\hline 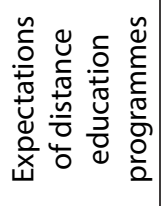 & & & $\begin{array}{l}\hat{0} \\
\$ \\
0\end{array}$ & 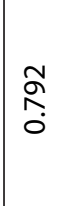 & $\stackrel{n}{n}$ & $\begin{array}{l}\overline{0} \\
0 \\
0\end{array}$ & 它 & $\frac{\nabla}{i n}$ & $\stackrel{m}{\tilde{m}}$ & $\begin{array}{l}\stackrel{\sim}{\mathcal{Z}} \\
\stackrel{0}{\circ}\end{array}$ \\
\hline 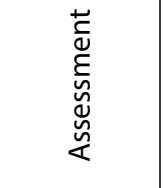 & & $\begin{array}{l}\stackrel{0}{\infty} \\
\infty \\
0 \\
0\end{array}$ & \begin{tabular}{l}
\multirow{+}{*}{} \\
$\stackrel{0}{0}$
\end{tabular} & $\begin{array}{l}\infty \\
0 \\
0 \\
0 \\
0\end{array}$ & \begin{tabular}{l}
0 \\
\multirow{j}{0}{} \\
0
\end{tabular} & \begin{tabular}{l}
\multirow{2}{*}{} \\
ஸे
\end{tabular} & $\begin{array}{l}\text { ô } \\
\hat{0} \\
0\end{array}$ & $\begin{array}{l}\text { ñ } \\
0\end{array}$ & $\begin{array}{l}\bar{n} \\
0 \\
0\end{array}$ & 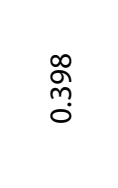 \\
\hline 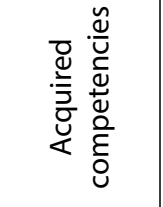 & 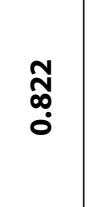 & $\begin{array}{l}\tilde{\hat{\sigma}} \\
\stackrel{0}{0}\end{array}$ & $\begin{array}{l}\hat{L} \\
0 \\
0\end{array}$ & $\begin{array}{l}\tilde{\sigma} \\
0 \\
0\end{array}$ & ஓ̊ ণ & $\begin{array}{l}\infty \\
\stackrel{0}{0} \\
0\end{array}$ & $\begin{array}{l}\infty \\
\text { Oొర } \\
0\end{array}$ & $\begin{array}{l}\bar{\Xi} \\
0\end{array}$ & $\begin{array}{l}\hat{\hat{n}} \\
0 \\
0\end{array}$ & $\begin{array}{l}\hat{\text { Oे }} \\
\text { on }\end{array}$ \\
\hline \multirow[t]{2}{*}{$\underset{\gtrless}{\rightleftarrows}$} & \begin{tabular}{l}
0 \\
\multirow{0}{0}{} \\
0
\end{tabular} & $\begin{array}{c}\stackrel{\Upsilon}{0} \\
\stackrel{0}{0}\end{array}$ & $\begin{array}{l}\bar{n} \\
\hat{0}\end{array}$ & $\begin{array}{l}n \\
\hat{O} \\
0 \\
0\end{array}$ & $\begin{array}{l}\hat{0} \\
\stackrel{0}{0}\end{array}$ & 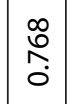 & $\bar{\varnothing}$ & 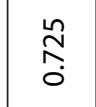 & $\begin{array}{l}\bar{o} \\
0 \\
0\end{array}$ & $\begin{array}{l}\text { 蔔 } \\
\text {. }\end{array}$ \\
\hline & 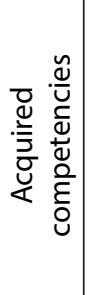 & 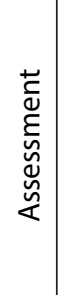 & 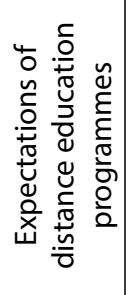 & 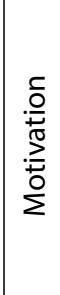 & 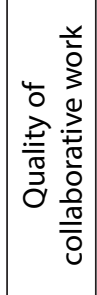 & 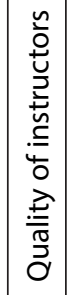 & 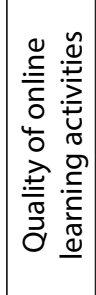 & 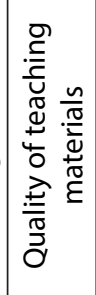 & 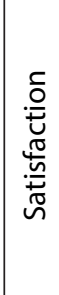 & 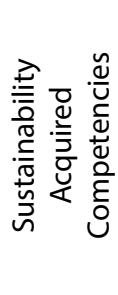 \\
\hline
\end{tabular}


Table 3. Model fit summary

\begin{tabular}{|c|c|}
\hline Criteria & Achieved values \\
\hline SRMR & 0.04 \\
\hline NFI & 0.787 \\
\hline
\end{tabular}

